\title{
Size, Value and Turn-of-the-Year Effect in the Egyptian Stock Market
}

\author{
Mohamed A. Shaker ${ }^{1} \&$ Khairy Elgiziry ${ }^{1}$ \\ ${ }^{1}$ Department of Business Administration, Faculty of Commerce, Cairo University, Egypt \\ Correspondence: Mohamed A. Shaker, Department of Business Administration, Faculty of Commerce, Cairo \\ University, Cairo, 12613, Egypt. Tel: 44-745-467-8886. E-mail: mashaker@foc.cu.edu.eg
}

Received: September 10, 2014

Accepted: September 16, 2014

Online Published: October 25, 2014

doi:10.5539/ijef.v6n11p90

URL: http://dx.doi.org/10.5539/ijef.v6n11p90

\begin{abstract}
This paper is an attempt to investigate the relation of financial anomalies, namely size, book-to-market and turn-of-the-year and their relation with risk and average return in the Egyptian stock market from 2003 to 2007. The sample consists of 55 stocks listed on the EGX100 and split into six portfolios sorted on size and book-to-market ratio based on Fama-French (1992) technique. The results show evidence that there is negative relationship between size and average return, and between value and average return for small stocks. Also, both size and book-to-market have negative relation with risk.
\end{abstract}

Keywords: financial anomalies, size, book-to-market, turn of the year effect, emerging markets finance

\section{Introduction}

Financial anomalies are statistical patterns that deviate from EMH/CAPM framework and caused by either misspecification of the asset pricing model or market inefficiency (Schwert, 2002). The two of the most prominent failures of the EMH/CAPM paradigm are size and value effects, especially in emerging markets because of the market disintegration (Harvey, 2001).

The process of valuation and estimating the cost of capital in emerging market is suffering from lack of transparency, illiquidity, government intervention, corruption, higher volatility, higher transaction cost and absence of governance. These obstacles violate the main assumptions of valuation in developed markets (Burner, Conroy, Estrada, Kritzman and Li). In addition, the financial theory is rich in discussing anomalies in developed markets in North America and Europe. However, emerging markets have not had sufficient attention (Zhang, Sun, \& Wang, 2008).

As an Emerging market, Egyptian stock market is of importance because of its number of listed securities (213), number of investors and volume of trading (2.3 billion) (Abd El Aal, 2011). Furthermore, it is more well-established than other markets in the MENA region and has attracted many investors over the past few years, resulting in a significant increase in the aggregate capitalization and in the market indices (Billmeier \& Massa, 2008).

The rest of the paper is organized as follows. In section 2, we provide the background of related works. Section 3 provides descriptions of data and sample. Section 4 focuses on methodology including the method of constructing portfolios used for empirical analysis. Section 5 shows the empirical study and analysis. Section 6 reports the concluding remarks.

\section{Theoretical Development}

Several types of models are discussed in academic literature. The capital asset pricing model (CAPM) is one of the few theoretical frameworks that have significant existence in practice. It indicates that the market beta is the only risk factor to explain cross section variation of expected stock returns. However, the validity of the CAPM has been challenged. Some tests of CAPM state that the estimates of beta for individual securities are inaccurate (Friend \& Blume, 1973; Fama \& MacBeth, 1973). Roll (1977) criticized the utility of the model due to its reliance on a market portfolio of risky assets that does not exist in real world. Some empirical tests work on modifying the CAPM's unrealistic assumptions such as Merton, 1973, Black, 1972 and Mayer, 1973.

Despite the serious criticisms against the CAPM, Ross (1976) proposed a new and different approach known as arbitrage pricing theory (APT), to describe the process of asset prices formation. He shows that the expected return on any risky asset can be explained by a linear combination of risk premiums and factor sensitivities. Yet, 
the APT does not stipulate what and how many factors should be included in the model. After that, several multifactor models that use macroeconomic factors have been suggested to explain cross-section of average return. Meanwhile, empirical studies have clarified common stock return anomalies not explained by the CAPM. For example, Banz (1981) concludes that small size firms provide higher average returns than big size ones. Basu (1983) finds that the portfolios with a higher (lower) earnings-price ratio (E/P) have higher (lower) average returns on U.S stocks. DeBondt and Thaler (1985) find an inverse relationship between the long-term past returns on NYSE stocks and their future returns. In contrast, Jegadeesh and Titman (1993) find a positive relationship between the short-term returns on NYSE stocks and their future returns. Fama and French (1993) identify a model with three common risk factors in the stock returns - an overall market factor, factors related to firm size (SMB) and those related to book-to-market equity (HML). Fama and French (1996) define 'financial anomalies' as the patterns in average returns that obviously are not explained by the CAPM. These are related to firm characteristics like size, earnings/price, cash flow/price, book-to-market equity, past sales growth, long-term past return, and short-term past return. There was a widespread blame for the Fama-French model when the risk factors were interpreted as the fundamental sources of risk. Daniel and Titman (1997) specifically rejected the Fama-French model and offered a more general model where size and book-to-market are firm characteristics and not risk factors as Fama and French introduced. The Fama and French risk-return framework is further extended by Carhart (1997) who introduced a price momentum factor as the fourth systematic risk factor. The price momentum factor represents the tendency of firms with negative past returns to earn negative future returns, and for firms with positive past returns to earn positive future returns. Chan and Faff (2005) also prolong Fama-French model by adding liquidity factor that represents the difference between the return on illiquid portfolios and the return on very liquid portfolios. Baek and Bilson (2014) demonstrate evidence that value and size are priced for financial and non-financial firms. Docherty, Chan and Easton (2013) conclude that size and value can explain the cross-section of asset returns in Australia from 1975 to 2006.

Researchers also test some of those models in emerging markets. For instance, Shum and Tang (2005) apply Fama-French three factor model in Hong Kong, Singapore and Taiwan and their empirical evidence is consistent with the US findings that the model can explain most of the variations in average returns. Lam, Li and So (2010) use Hong Kong monthly data to test the four-factor asset pricing model "momentum-augmented Fama-French three factor model". Their model does well in explaining variations in expected returns. Their findings documented that all the four factors are significant but the intercepts are not. Eom and Park (2008) examine the Fama-French test to the three-factor model in the Korean emerging stock market. They reject the model in their full sample periods and in most sub-periods. Results are not consistent with those in developed markets. They cannot get conclusive results pertaining to Daniel-Titman characteristics model. Finally, Lischewski and Vorokova (2012) support the presence of market, size and value factors in the polish stock market during the period January 1996 to March 2009.

The theoretical development marks the central position of the Fama-French framework in the state of the art that urges the authors to utilize it as a target for their tests.

\section{Description of Data and Sample}

The most active 100 securities "EGX 100 index" are consisted of the sample of the research between January 2003 to December 2007, excluding 45-companies due to data unavailability. The empirical study requires market and accounting data such as monthly closing price, 91-days treasury bills, monthly market return, shares outstanding, trading volume, Market capitalization and $\mathrm{M} / \mathrm{B}$ ratio.

\section{Methodology}

"B/L, B/M, B/H, S/L, S/M and S/H" are formed in accordance with Fama-French methodology (1993). The excess return on each portfolio equals the monthly value- weighted average rate of return minus the risk-free interest rate $\left(\mathrm{R}_{\mathrm{i}}-\mathrm{R}_{\mathrm{f}}\right)$.

In each year of the sample period, the stocks are divided into two groups- big (B) and small (S)- based on their market capitalization. The sample size is also divided into three groups based on their BE/ME ratio-high $(\mathrm{H})$ with top $30 \%$, medium (M) with middle $40 \%$ and low $(\mathrm{L})$ with bottom $30 \%$. The constructing portfolios are as follows: 
Table 1. Size-B/M sorted portfolios

\begin{tabular}{ccc}
\hline Size & B-M Ratio & Name \\
\hline \multirow{3}{*}{ Big (B) } & Low (L) & B/L \\
& Medium (M) & B/M \\
& High (H) & B/H \\
Small (S) & Low (L) & S/L \\
& Medium (M) & S/M \\
& High (H) & S/H \\
\hline
\end{tabular}

There are six intersection portfolios, B/L, B/M, B/H, S/L, S/M, S/H - that are formed from the intersection of the two size-and three BE/ME groups. For example, $\mathrm{S} / \mathrm{L}$ consists of stocks that are in the small size group and the low BE/ME group.

\section{Empirical Analysis}

\subsection{Characteristics of Portfolios}

Table 2. Average number of stocks in each portfolio by year

\begin{tabular}{lccccccc}
\hline Portfolios Year & $\mathbf{B} / \mathbf{H}$ & $\mathbf{B} / \mathbf{M}$ & $\mathbf{B} / \mathbf{L}$ & $\mathbf{S} / \mathbf{H}$ & $\mathbf{S} / \mathbf{M}$ & $\mathbf{S} / \mathbf{L}$ & Total \\
\hline 2003 & 2 & 14 & 11 & 15 & 8 & 5 & 55 \\
2004 & 4 & 10 & 13 & 13 & 12 & 3 & 55 \\
2005 & 3 & 11 & 13 & 14 & 11 & 3 & 55 \\
2006 & 5 & 13 & 10 & 13 & 8 & 6 & 55 \\
2007 & 4 & 13 & 10 & 13 & 9 & 6 & 55 \\
Average & 3.6 & 12.2 & 11.4 & 13.6 & 9.6 & 4.6 & 55 \\
\hline
\end{tabular}

Table 2 demonstrates the number of stocks in the six constructing portfolios on average. It is observed that the largest portfolio is $\mathrm{S} / \mathrm{H}$, with an average of 13.6 firms. At the other extreme the smallest portfolio is $\mathrm{B} / \mathrm{H}$, with an average of 3.6 firms only. This is not in line with the literature in almost all developed markets, because the number of stocks in each portfolio is small. In addition, the largest size portfolios $(\mathrm{B} / \mathrm{H}, \mathrm{B} / \mathrm{H}, \mathrm{B} / \mathrm{M})$ contain 27 stocks (up to $49 \%$ from sample size on average), and the smallest size portfolios $(\mathrm{S} / \mathrm{H}, \mathrm{S} / \mathrm{M}, \mathrm{S} / \mathrm{L}$ ) involve 28 stocks (up to $51 \%$ from sample size on average). According to $\mathrm{B} / \mathrm{M}$ ratio portfolios, the highest $\mathrm{B} / \mathrm{M}$ portfolios $(\mathrm{B} / \mathrm{H}, \mathrm{S} / \mathrm{H})$ consist of 17 stocks (up to $31 \%$ from sample size), while the lowest B/M portfolios (B/L, S/L) contain 16 stocks ( up to $29 \%$ from sample size on average).

\subsection{Size and Value Effect}

We can divide table 3 into three main segments:

- The first segment is related to the premiums of Egyptian factors $R_{m}-R_{f}, S M B, H M L, W M L$, and IMV. The market factor " $\mathrm{R}_{\mathrm{m}}-\mathrm{R}_{\mathrm{f}}$ " has an average premium of $-4.48 \%$ and a standard deviation of $7.49 \%$. The size premium is the biggest premium with an average of $2.33 \%$ but the value premium is the lowest with an average of $5.30 \%$. The figures of Kurtosis are significantly high for size premium, value premium and momentum premium. However, it is significantly low for market premium and liquidity premium. Finally, the positive size premium is consistent with most of the other countries.

- The second segment is related to monthly excess return for $\mathrm{B} / \mathrm{H}, \mathrm{B} / \mathrm{M}, \mathrm{B} / \mathrm{L}, \mathrm{S} / \mathrm{H}, \mathrm{S} / \mathrm{M}$ and $\mathrm{S} / \mathrm{L}$. In line with the most common evidence in literature review, there is negative relationship between size and average return. Surprisingly, the relationship between value and average return is negative for small stocks and unclear for big size stocks. This result disagrees with that of Fama and French $(1992,1993)$ of a strong positive relationship between value and average return. All the portfolios have large volatility with an average of $23.3 \%$. There is, in addition, positive Skewness for all portfolios except B/M. The kurtosis for all portfolios is close to 3 except B/L and $\mathrm{S} / \mathrm{L}$. The kurtosis values for $\mathrm{B} / \mathrm{L}$ and $\mathrm{S} / \mathrm{L}$ are due to the presence of outliers.

- The third segment is related to standard deviation as proxy for risk, the relation between risk and both size and book-to-market ratio. It is observed that the return on market portfolio is $7.09 \%$. This means the six portfolios $\mathrm{B} / \mathrm{H}, \mathrm{B} / \mathrm{M}, \mathrm{B} / \mathrm{L}, \mathrm{S} / \mathrm{H}, \mathrm{S} / \mathrm{M}, \mathrm{S} / \mathrm{L}$ have higher return than market portfolio and this ranges from $9.3 \%$ to $56.3 \%$. It is also noteworthy that there is negative relationship between risk and size. The big size portfolios expose to risk $20.9 \%$ on average. While the small size portfolios expose to an average of $25.16 \%$. Regarding the relation 
between risk and book-to-market ratio, there is negative relationship. The highest $\mathrm{B} / \mathrm{M}$ ratio portfolios $(\mathrm{B} / \mathrm{H}, \mathrm{S} / \mathrm{H})$ fluctuate by $9.7 \%$ on average. However, the lowest B/M ratio portfolios (B/L, S/L) fluctuate by $50 \%$ on average.

Table 3. Size and BE-ME

\begin{tabular}{ccccccc}
\hline Description Variables & Mean & SD & Min & Max & Skewness & Kurtosis \\
\hline $\mathrm{B} / \mathrm{H}$ & -5.87 & 10 & -32.4 & 23.2 & 0.5 & 2.30 \\
$\mathrm{~B} / \mathrm{M}$ & -7.08 & 9.3 & -34.55 & 18.5 & -0.2 & 2.1 \\
$\mathrm{~B} / \mathrm{L}$ & -4.78 & 43.5 & -158.05 & 182.1 & 0.3 & 9.2 \\
$\mathrm{~S} / \mathrm{H}$ & -7.27 & 9.4 & -30 & 15.3 & 0.11 & 0.28 \\
$\mathrm{~S} / \mathrm{M}$ & -6.5 & 11.3 & -36.8 & 23.8 & 0.44 & 1.49 \\
$\mathrm{~S} / \mathrm{L}$ & 1.65 & 56.3 & -123 & 302 & 3.1 & 16.3 \\
$\mathrm{R}_{\mathrm{M}}-\mathrm{R}_{\mathrm{F}}$ & -4.48 & 7.49 & -27.75 & 9.89 & -0.59 & 0.69 \\
$\mathrm{SMB}$ & 2.33 & 24.87 & -55.43 & 120.89 & 1.87 & 9.48 \\
$\mathrm{HML}$ & -5.30 & 35.88 & -167.84 & 68.38 & -1.98 & 8.05 \\
$\mathrm{WML}$ & 0.55 & 7.09 & -11.3 & 32.89 & 1.92 & 7.39 \\
$\mathrm{IMV}$ & -2.59 & 13.23 & -38.03 & 30.74 & -0.31 & 1.10 \\
\hline
\end{tabular}

The table explains summary statistics including the first four moments for monthly explanatory returns and excess returns for dependent 6 size-B/M portfolios (in percent) from January 2003 to December $2007 . R_{m}-R_{f}$, SMB, HML, WML and IMV are formed in accordance with Fama-French methodology (1993). Accordingly, the first factor is $\mathrm{R}_{\mathrm{m}}-\mathrm{R}_{\mathrm{f}}=$ excess return on market portfolio. The second factor is SMB "small minus big" = the difference between the return on portfolio of small stocks $(\mathrm{S} / \mathrm{L}, \mathrm{S} / \mathrm{M}, \mathrm{S} / \mathrm{H})$ and the return on a portfolio of large stocks $(\mathrm{B} / \mathrm{L}, \mathrm{B} / \mathrm{M}, \mathrm{B} / \mathrm{H})$. The third factor is HML "High minus Low" = the difference between the return on portfolio of high $\mathrm{B} / \mathrm{M}$ ratio $(\mathrm{B} / \mathrm{H}, \mathrm{S} / \mathrm{H})$ and the return on portfolio of low $\mathrm{B} / \mathrm{M}$ ratio $(\mathrm{B} / \mathrm{L}, \mathrm{S} / \mathrm{L})$. The fourth factor is WML (Note 1) "winners minus losers" = the difference between the return on winners portfolio $(\mathrm{B} / \mathrm{W}, \mathrm{S} / \mathrm{W})$ and the return on losers portfolio (B/Losers, S/Losers). The fifth factor is IMV (Note 2): liquidity factor "illiquid minus very liquid" = the difference between the return on portfolio of illiquid stocks $(B / I, S / I)$ and the return on portfolio of very liquid portfolio $(\mathrm{B} / \mathrm{V}, \mathrm{S} / \mathrm{V})$.

\subsection{Turn-of-the-Year Effect}

Turn-of-the-year effect or January effect is one of the most recognized anomalies in finance literature. Since Keim (1983) and Roll (1983) documented that the returns in January tend to be greater than any other month of the year. Subsequent research confirmed these findings and identified that the effect is primarily concentrated in smaller firms particularly in those with low share prices and those that have underperformed in the past (Moller \& Zilca, 2008). According to Keim (1983), the tax-loss selling hypothesis is that investors sell the losing stocks in their portfolio at the end of the year to achieve tax benefits and reposition their portfolios in January.

The official financial year in Egypt starts on $1^{\text {st }}$ July and ends on $30^{\text {th }}$ June every year, which could push the investors to rebalance their portfolios to cope with government's budget dates. As a result, we consider July effect as an analogous to January effect for the USA.

Table 4. Tests for July seasonal in the dependent returns explanatory returns

\begin{tabular}{cccccc}
\hline Portfolio & $\boldsymbol{a}$ & $\boldsymbol{b}$ & $\boldsymbol{t}(\boldsymbol{a})$ & $\boldsymbol{t}(\boldsymbol{b})$ & $\boldsymbol{R}^{\mathbf{2}}$ \\
\hline $\mathrm{B} / \mathrm{H}$ & -5.83 & -0.35 & -4.0 & -0.074 & 0.00 \\
$\mathrm{~B} / \mathrm{M}$ & -7.54 & 5 & -5.73 & 1.15 & 0.024 \\
$\mathrm{~B} / \mathrm{L}$ & -8.42 & 39.9 & -1.41 & 2.014 & 0.071 \\
$\mathrm{~S} / \mathrm{H}$ & -7.78 & 5.62 & -5.90 & 1.28 & 0.03 \\
S/M & -6.92 & 4.6 & -4.31 & 0.861 & 0.014 \\
S/L & 1.9 & -2.60 & 0.235 & -0.097 & 0.000 \\
R $-\mathrm{R}_{\mathrm{F}}$ & -4.6 & 1.37 & -4.3 & 0.39 & 0.003 \\
SMB & 3.5 & -12.85 & -15.73 & -1.104 & 0.022 \\
HML & -3.87 & 1.99 & -0.76 & -0.934 & 0.016 \\
WML & 0.373 & -4.80 & -1.147 & 0.60 & 0.082 \\
IMV & -2.15 & & -0.77 & 0.011 \\
\hline
\end{tabular}

Note. Statistical significance at the $5 \%$ level. 
In order to investigate the July effect, this paper uses dummy variable regression. The intercept measures the average returns for non-January months and the slopes on a dummy measure differs between average returns in January and average returns in other months.

$$
R_{i}-R_{f}=a+b \operatorname{July}(t)+e(t)
$$

The results indicate that there are no exact seasonal effects in July for all portfolios as risk factors with only one exception for B/L, which has higher average return in July and the increase is in excess of 39.9\%. These are consistent with Bahl (2006).

The table reports the empirical findings of July seasonal effect. B/H, B/M, B/L, S/H, S/M and S/L are size-B/M sorted portfolios. $R_{i}$ is the return on portfolio $i, R_{f}$ is the risk-free rate of return and $R_{m}$ is the return on market portfolio. SMB is the size factor "small minus big". HML is the value factor "high minus low". IMV is the liquidity factor "illiquidity minus very liquidity". WML is the momentum factor "winners minus losers". July (t) is a dummy variable that is 1 if month $t$ is January and 0 otherwise

\section{Conclusion}

The study tries to examine three anomalies in the Egyptian stock market, namely, size, Book-to-Market and seasonal effect. To do this, the Fama-French (1992) technique to construct portfolios is followed using 55 stocks listed on the EGX100 index in the Egyptian stock market. The results explain the negative relation between size and average return. Regarding the relation between $\mathrm{B} / \mathrm{M}$ and average return for small stocks is negative. However, it is unstable for big stocks. There is also negative relation between size and risk and negative between $\mathrm{B} / \mathrm{M}$ ratio and risk. Finally, the seasonal effect is not obvious between 2003 and 2007.

\section{Acknowledgement}

The authors would like to thank Khaled Hussainey; Professor of Accounting at Plymouth University; Mohamed Eissa; Assistant Professor in Finance at Qatar University, Amr Kotb; Senior Lecturer of Accounting and Finance at Anglia Ruskin University and Robert Cressy; Professor of Entrepreneurship and Finance at Brimingham University for their beneficial comments.

\section{References}

Baek, S., \& Bilson, J. F. O. (2014). Size and value risk in financial firms. Journal of Banking and Finance. http://dx.doi.org/10.1016/j.jbankfin.2014.02.011

Bahl, B. (2006). Testing the Fama and French Three-factor model and its variants for the Indian stock returns. SSRN, Working Paper $\quad$ No. 950899. Retrieved from http://papers.ssrn.com/sol3/papers.cfm?abstract_id=950899

Banz, R. (1981). The relationship between return and market value of common stocks. Journal of Financial Economics, 9(1), 3-18. http://dx.doi.org/10.1016/0304-405X(81)90018-0

Barry, B. C. (2002). Robustness of size and value effects in emerging equity markets, 1985-2000. Emerging Markets Review, 3, 1-30. http://dx.doi.org/10.1016/S1566-0141(01)00028-0

Basu, S. (1983). The relationship between earnings' yield, market value and return for NYSE common stocks: further evidence. Journal of Financial Economics, 12(1), 129-156. http://dx.doi.org/10.1016/0304-405X(83)90031-4

Bekaert, G., Harvey, C. R., \& Lundblad, C. (2007). Liquidity and expected returns: lessons from emerging markets. Review of Financial Studies, 20(5), 1783-1831. http://dx.doi.org/10.1093/rfs/hhm030

Black, F. (1972). Capital market equilibrium with restricted borrowing. Journal of Business, 45(3), 444-455. http://dx.doi.org/10.1086/295472

Black, F., Jensen, M. C., \& Scholes, M. S. (1972). The capital asset pricing model: Some empirical tests. In M. C. Jensen (Ed.), Studies in the Theory of Capital Markets (pp. 79-121). New York: Praeger.

Blume, M. E., \& Friend, I. (1973). A new look at the capital asset pricing model. Journal of Finance, 28(1), $19-33$. http://dx.doi.org/10.1111/j.1540-6261.1973.tb01342.x

Brennan, M. J., \& Subrahmanyam, A. (1996). Market microstructure and asset pricing: on the compensation for illiquidity in stock returns. Journal of Financial Economics, 41(3), 441-464. http://dx.doi.org/10.1016/0304-405X(95)00870-K

Bruner, R. F. (2002). Introduction to "Valuation in Emerging Markets". Emerging Markets Review, 3, $310-324$. http://dx.doi.org/10.1016/S1566-0141(02)00039-0 
Chamberlain, G., \& Rothschild, M. (1983). Arbitrage, factor structure, and mean variance analysis on large asset markets. Econometrica, 51(5), 1281-1304. http://dx.doi.org/10.2307/1912275

Cho, D., Elton, E., \& Gruber, M. (1984). On the robustness of the Roll and Ross arbitrage pricing theory. Journal of Financial and Quantitative Analysis, 19(1), 1-10. http://dx.doi.org/10.2307/2330997

Connor, G., \& Sehgal, S. (2001). Tests of the Fama and French model in India. Discussion paper, 379. Financial Markets Group, London School of Economics and Political Science, London, UK.

Daniel, K., \& Titman, S. (1997). Evidence on the characteristics of cross-sectional variation in stock returns. Journal of Finance, 52(1), 1-33. http://dx.doi.org/10.2307/2329554

Docherty, P., Chan, H., \& Easton, S. (2013). Australian evidence on the implementation of the size and value premia. Accounting and Finance, 53, 367-391. http://dx.doi.org/10.1111/j.1467-629X.2011.00464.x

Eom, K. S., \& Park, J. (2008). Evidence on the three-factor and characteristics models: Korea. SSRN, Working paper, No. 1329664. Retrieved from http://papers.ssrn.com/sol3/papers.cfm?abstract_id=1329664

Fama, E. F., \& French, K. R. (1992). The cross-section of expected stock returns. Journal of Finance, 47, 427466. http://dx.doi.org/10.2307/2329112

Fama, E. F., \& French, K. R. (1993). Common risk factor in the returns of stock and bonds. Journal of Financial Economics, 33(1), 3-56. http://dx.doi.org/10.1016/0304-405X(93)90023-5

Fama, E., \& MacBeth, J. D. (1973). Risk, return and equilibrium: Empirical tests. Journal of Political Economy, 81(3), 607-636. http://dx.doi.org/10.1086/260061

Harvey, C. H. (2001). Asset Pricing in Emerging Markets. In O. Ashenfelter (Ed.), International Encyclopedia of The Social and Behavioral Sciences (pp. 840-845). Elsevier Science Limited. http://dx.doi.org/10.1016/B0-08-043076-7/02268-3

Hodrick, R. J., \& Zhang, X. (2001). Evaluating the specification errors of asset pricing models. Journal of Financial Economics, 62(2), 327-376. http://dx.doi.org/10.1016/S0304-405X(01)00080-0

Keim, D. B. (1983). Size-related anomalies and stock return seasonality: further empirical evidence. Journal of Financial Economics, 12(1), 13-24. http://dx.doi.org/10.1016/0304-405X(83)90025-9

Lam, K. S. K., Li, F. K., \& So, S. M. S. (2010). On the validity of augmented Fama-French four-factor model. Review of Quantitative Finance and Accounting, 35(1), 89-111. http://dx.doi.org/10.1007/s11156-009-0151-x

Lischewski, J., \& Voronkova, S. (2012). Size, value and liquidity. Do they really matter on an emerging stock market (pp. 8-25). http://dx.doi.org/10.1016/j.ememar.2011.09.002

Merton, R. (1973). The intertemporal capital asset pricing model. Econometrica, 141(5), 867-887. http://dx.doi.org/10.2307/1913811

Moller, N., \& Zlica, S. (2008). The evolution of the January effect. Journal of Banking \& Finance, 32(3), 447457. http://dx.doi.org/10.1016/j.jbankfin.2007.06.009

Myers, D. (1973). Non-marketable assets and the determination of the capital asset prices in the absence of a riskless assets. Journal of Business, 46(2), 258-267. http://dx.doi.org/10.1016/0378-4266(93)90019-A

Pastor, L., \& Stambaugh, R. F. (2003). Liquidity Risk and Expected Stock Returns. Journal of Political Economy, 111(3), 642-685. http://dx.doi.org/10.1086/374184

Pereiro, L. E. (2006). The practice of investment valuation in emerging market: Evidence from Argentina. Journal of Multinational Financial Management, $160(2), \quad$ 183. http://dx.doi.org/10.1016/j.mulfin.2005.06.001

Roll, R. (1977). A Critique of the Asset Pricing Theory's Tests. Part 1: On Past and Potential Testability of the Theory. Journal of Financial Economics, 4(2), 129-176. http://dx.doi.org/10.1016/0304-405X(77)90009-5

Roll, R. (1983). Vas ist das? The turn-of-the-year effect and the risk premia of small firms. Journal of Portfolio Management, 9(2), 18-28. http://dx.doi.org/10.3905/jpm.1983.18

Ross, S. A. (1976). An Arbitrage Theory of Capital Asset Pricing. Journal of Economic Theory, 13(2), 341-360. http://dx.doi.org/10.1016/0022-0531(76)90046-6

Schwert, W. G. (2002). Anomalies and Market Efficiency. NBER, Working Paper, No. 9277. Retrieved from http://www.nber.org/papers/w9277.pdf 
Shum, W. C., \& Tang, G. Y. N. (2005). Common risk factors in returns in Asian emerging stock markets. International Business Review, 14, 695-717. http://dx.doi.org/10.1016/j.ibusrev.2005.09.001

Zhang, Z., Sun, W., \& Wang, H. (2008). A new perspective on financial anomalies in emerging markets: the case of China. Applied Financial Economics, 18, 1681-1695. http://dx.doi.org/10.1080/09603100701735946

\section{Notes}

Note 1. WML is constructed based on two size $(B, S)$ three momentum (W, M, L) sorted portfolio (B/W, B/M, $\mathrm{B} /$ Losers and $\mathrm{S} / \mathrm{W}, \mathrm{S} / \mathrm{M} \mathrm{S} /$ Losers).

Note 2. IMV is constructed based on two size $(\mathrm{B}, \mathrm{S})$ three Liquidity $(\mathrm{I}, \mathrm{M}, \mathrm{V})$ sorted portfolio $(\mathrm{B} / \mathrm{I}, \mathrm{B} / \mathrm{M}, \mathrm{B} / \mathrm{V}$ and $\mathrm{S} / \mathrm{I}, \mathrm{S} / \mathrm{M}, \mathrm{S} / \mathrm{V})$.

\section{Copyrights}

Copyright for this article is retained by the author(s), with first publication rights granted to the journal.

This is an open-access article distributed under the terms and conditions of the Creative Commons Attribution license (http://creativecommons.org/licenses/by/3.0/). 